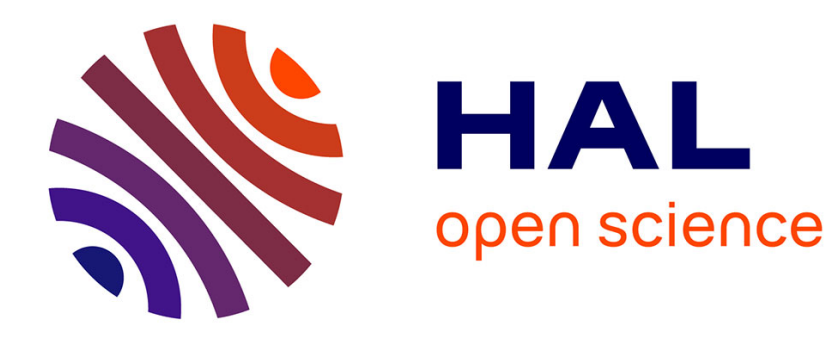

\title{
Ruways Salîm's new Inscriptions (in Jordan): a linguistic analysis
}

\author{
Saba Farès
}

\section{To cite this version:}

Saba Farès. Ruways Salîm's new Inscriptions (in Jordan): a linguistic analysis. Semitica et Classica, 2017, 10, pp.215-223. halshs-01730851

\section{HAL Id: halshs-01730851 \\ https://shs.hal.science/halshs-01730851}

Submitted on 24 Sep 2021

HAL is a multi-disciplinary open access archive for the deposit and dissemination of scientific research documents, whether they are published or not. The documents may come from teaching and research institutions in France or abroad, or from public or private research centers.
L'archive ouverte pluridisciplinaire HAL, est destinée au dépôt et à la diffusion de documents scientifiques de niveau recherche, publiés ou non, émanant des établissements d'enseignement et de recherche français ou étrangers, des laboratoires publics ou privés. 


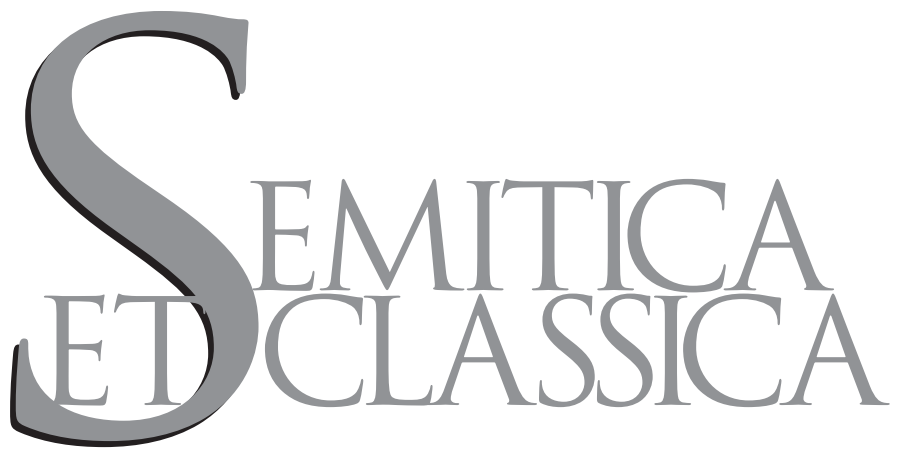

\title{
REVUE INTERNATIONALE D'ÉTUDES ORIENTALES ET MÉDITERRANÉENNES \\ INTERNATIONAL JOURNAL OF ORIENTAL AND MEDITERRANEAN STUDIES
}

\section{VOLVMEN X 2017}

\author{
Directrice \\ MARIA GOREA \\ Comité de rédaction \\ Cécile Dogniez Renée Koch Piettre \\ Christophe Lemardelé Hedwige Rouillard-BonRaisin
}




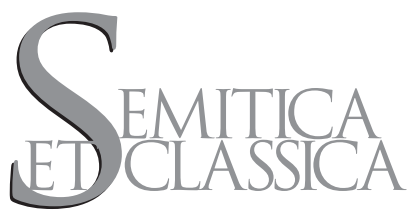

Revue annuelle publiée par l'Association Semitica \& classica, avec le concours du CNRS et le soutien de 1'UMR 8167 «Orient \& Méditerranée » (Mondes sémitiques, Antiquité classique et tardive, Monde byzantin, Médecine grecque, Islam médiéval, Mondes pharaoniques).

\section{Directrice \\ MARIA GOREA}

\section{Comité de rédaction}

Cécile Dogniez, Renée Koch Piettre,

Christophe Lemardelé,

Hedwige Rouillard-BonRaisin

\section{Comité scientifique}

En France :

VÉRONIQUE BOUdON-Millot (CNRS),

Françoise Briquel ChatonNet (CNRS),

FRANÇOIS BRON (EPHE),

IWONA GAJDA (CNRS),

RoBert HaWley (EPHE),

PhilipPe HofFMANN (EPHE),

Maria-Grazia Masetti Rouault (ePhe),

BrigitTe Mondrain (EPHE),

Olivier MunNICH (UNIVERSITÉ PARIS IV - SORBONNE),

LAÏLA NEHMÉ (CNRS),

MADELEINE SCOPELlO (CNRS),

ARNAUd SÉRANDOUR (EPHE),

VINCENT ZARINI (UNIVERSITÉ PARIS IV - SORBONNE).

\section{À l'étranger :}

Maria-Giulia Amadasi-GuZzo (ROME),

AleXANDRA AVANZINI (BOLOGNE),

FloRENTINO GARCÍA-MARTíNEZ (LOUVAIN),

ARIE VAN DER KOOIJ (LEYDE),

Michael LeCKER (JÉRUSALEM),

MiCHEL AL-MAQDISSI (DAMAS),

HERBERT NiEHR (TÜBINGEN),

Gregorio del Olmo Lete (Barcelone),

SERGio Ribichini (ROME),

BENJAMIN SASS (TEL AVIV),

SHAUl SHAKed (JÉRUSALEM),

DAVID TAYLOR (OXFORD),

Peter Van Nuffelen (GAND),

JUAN PABLO VITA (MADRID).

\section{Comité de patronage}

Président :

Véronique Boudon-Millot (PARIS), Directrice de l'UMR « Orient \& Méditerranée ».

MoniQue AlexANDRe (PARIS),

Nicole Belayche (PARIS),

Jean-Claude Cheynet (Paris),

Gilles Dorival (AIX-MARSEILLE),

MOHAMMED FANTAR (TUNIS),

NATALIo Fernández Marcos (MADRID),

ISRAEL FINKELSTEIN (TEL AVIV),

JEAN-LUC FOURNET (PARIS),

MARguerite HARL (PARIS),

HANI HAYAJNEH (AMMAN),

BERNHARD LANG (PADERBORN),

MARIO LiVERANi (ROME),

Dennis Pardee (Chicago),

Émile Puech (Jérusalem),

Christian JULIEN Robin (PARIS),

JOHN SCHEID (PARIS),

GuY STROUMSA (JÉRUSALEM),

MiCHEL TARDIEU (PARIS),

Julio TREBolle-BARRERA (MADRID).

La revue Semitica \& classica est ouverte à toutes les disciplines concernées par les études orientales et méditerranéennes depuis le second millénaire avant l'ère chrétienne jusqu'aux premiers siècles de l'Islam.

Elle couvre l'aire culturelle s'étendant de la Méditerranée occidentale au Moyen-Orient et privilégie les approches transversales et les démarches scientifiques novatrices.

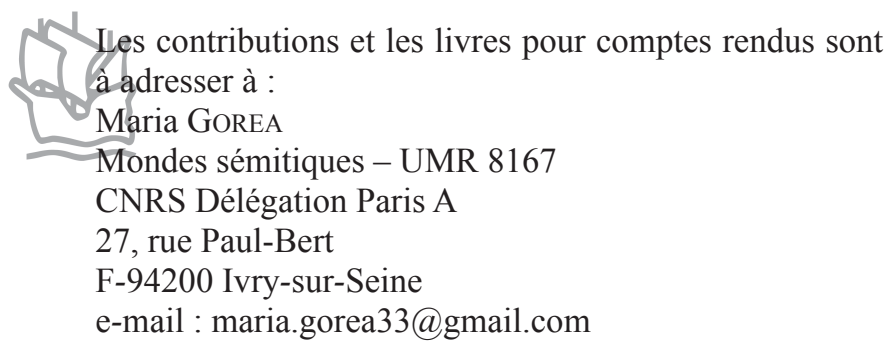
Les articles adressés à la Directrice sont soumis au comité de lecture et à une expertise doublement anonyme. 


\section{SOMMAIRE}

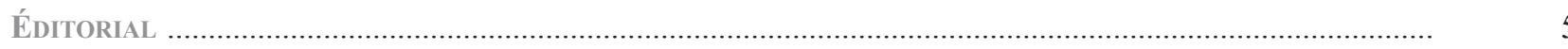

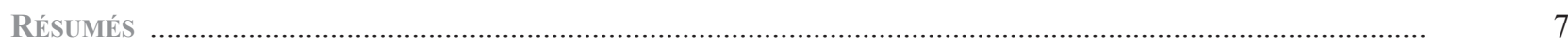

\section{ARTICLES}

STÉPHANIE ANNA LODDo - Une nouvelle édition de deux textes akkadiens : la Prophétie d'Uruk et la Prophétie dynastique

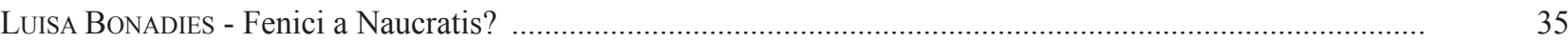

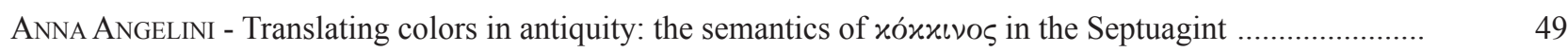

ÉTIENNE NODET - La synagogue et l'autorité scripturaire ......................................................................... 59

MAREN R. NieHofF - Philon d'Alexandrie à Rome : les conséquences intellectuelles d'un voyage ................. 81

FABIo EugENIO BETTI - L'aquila e il serpente: osservazioni su un frammento architettonico dall'Arabia Felix 95

SAMUEL C. BARRY - Comparing the terminology of the major Syriac and Arabic translations

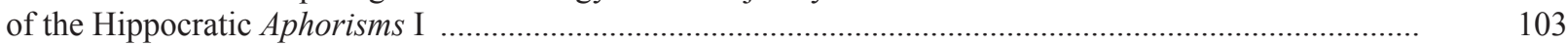

InNocent HimbazA - Le Pentateuque samaritain de Fribourg (Suisse) : un premier regard comparatif avec les manuscrits de Dublin et de Sichem avec les manuscrits de Dublin et de Sichem

\section{CORRESPONDRE DANS L'ANTIQUITÉ : LETTRES ET MESSAGES EN TOUS SENS}

SYlVIE DONNAT - Les lettres aux morts de l'Égypte pharaonique : les bénéfices d'une communication écrite avec l'ancêtre

DOMINIQUE LEFÈVRE - Épistolographie et diplomatique : la rédaction d'une lettre aux dieux sous la XXIe dynastie

FLORENCE MALBRAN-LABAT - Une correspondance au royaume d'Ougarit : standards et variété

ÉRIC LHÔTE - Correspondre avec les dieux, d'après les nouvelles lamelles oraculaires de Dodone : les cas de réponse de l'oracle

VARIA

Françoise Briquel Chatonnet, Jimmy Daccache, Robert Hawley - Notes d'épigraphie et de philologie phéniciennes. 3

Khaled MeLLitI - Une inscription punique inédite de Carthage

Mounir Arbach, JÉRÉMIE SchietTeCATTE - Inscriptions sabéennes du Jabal Riyām (Yémen) et nouvel éclairage sur les rois de Saba' au II ${ }^{\mathrm{e}}$ siècle de l'ère chrétienne

IWONA GAJDA, FrANÇOIS BRON - Les inscriptions sudarabiques découvertes dans le wādī ‘Alma

SABA FARÈS - Ruways Salīm's new inscriptions (in Jordan): a linguistic analysis

Mohammad I. Ababneh, FAhd M. Al-OtAiBI - New Safaitic inscriptions from Wādī Ru'eila 


\section{Hommages}

Émilia MASSON (1940-2017)

Javier TEIXIDOR (1930-2017)

Francolino José GonçALVES (1943-2017)

L'illustration de la vignette, sur la couverture, combine deux silhouettes - navigateurs, voyageurs? - empruntées à une stèle romaine, actuellement au Landesmuseum de Trèves, et des vagues inspirées d'un relief d'époque romaine se trouvant à la Glyptothèque Ny Carlsberg de Copenhague (dessin de M. Gorea).

Sous les eaux court la citation soluite uela citi de l'Énéide de Virgile-récit non d'un naufrage, mais d'un audacieux périple.

Les beaux vers qui précèdent éclairent le travail de tout chercheur: Præcipites uigilate, uiri, et considite transtris ; soluite uela citi : " Vite à vos bancs, amis, debout! Mettez à la voile! » (IV, 573-574).

Maquette et maquette de couverture

LUIGI FABII

Mise en pages et secrétariat de rédaction

EMMANUELLE CAPET

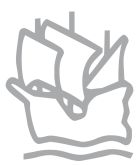

(C) 2017 Brepols Publishers n.v., Turnhout, Belgium

All rights reserved. No part of this publication may be reproduced, stored in a retrieval system, or transmitted, in any form or by any means, electronic, mechanical, photocopying, recording, or otherwise, without the prior permission of the publisher.

$\mathrm{D} / 2017 / 0095 / 292$

ISBN 978-2-503-54702-2

ISSN 2031-5937

Printed on acid-free paper (C) BREPOLS PUBLISHERS 


\section{SABA FARÈs Ruways Salīm's new inscriptions (in Jordan): a linguistic analysis}

\section{THE CONTEXT OF DISCOVERY AND THE TEXTS*}

In 1997, during our fieldwork at wādī Ramm, we explored a place locally known as Ruways Salìm, found at the left entrance of wādī Umm Saḥm (figure 1) ${ }^{1}$, southeast of the village of Ramm.

Ruways Salìm is a raised platform protected by small hills. The archaeological remains of prehistoric activity are visible on the ground (FARÈs 2013, pp. 33-35). Several dispersed blocks are engraved. There, we found engravings of animals often accompanied by a series of names of people. One block stood out from the crowd: it raised itself on the edge, at the entrance of the platform. Its smooth side is engraved and directed towards the route, in other words, towards the west (figure 2).

Only the lower half is engraved, the other half has a rough surface. This block is in red sandstone and the characters are in good general condition. The written form is typically regional: pretty characters with a height of around $20 \mathrm{~cm}$ for the letter $l \bar{a} m$. We counted twelve texts of length 5 to 21 letters.



Figure 1 - Localisation of the site.

* The project at Ramm is financed by the Department of Human and Social Sciences, Archaeology and Heritage at the French Ministry of Foreign Affairs and International Development. I am grateful to all who supported the project at MAEDI. Without the local population at Ramm, especially Hassan
'Awdeh al-Zalabyeh, we would not have carried out our field researches and made these discoveries.

1. I mentioned the site for the first time in 1996, in a first preliminary report of the 1997 expedition (FARÈS-DRAPPEAU 1996, p. 273). 
THE UPPER PART (figures 3 and 4)

\section{RS 1. l-Rbn $b n{ }^{\prime} z z$}

$R b n$ son of ' $z z$.

Rbn: masculine anthroponym. It is only mentioned in Harding \& Littmann's lexicon as dubious (HARDING \& LitTMAnN 1952, nos. 406 and 465). With Ibn Hazm we come across ربّان, the radical letters of which refer back to our text. He is the son of Hulwān ibn 'umrān ibn al-Hāẫ

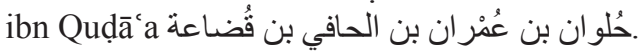

'zz: patronym "power, strength," known in a Thamudic inscription at Ramm (HARDING \& LitTMANN 1952, no. 152 ; KING 1990 , p. 582). It is known in Nabataean (CANTINEAU 1930, p. 129). It is confirmed in Safaitic and in South Arabian (HARDING 1971). The repetition of the letter zay could refer back to a name either of type of type عزيز/عزاز. Moreover, today, it is a very common anthroponym.

RS 2. l- ${ }^{\prime} b d$ bn $M h b b b \underline{d}$ 'l Mzn

'bd fils de $M h b b$ of the clan of 'l Mzn. ${ }^{2}$

' $b d$ : masculine anthroponym equivalent to the Arabic عَبْ "worshipper, servant," name known in Semitic vocabulary, either as an anthroponym or as an element of theophoric names. ${ }^{3}$ As an anthroponym, it is known in Thamudic inscriptions in the region of Ramm (HARDING \& LitTMANN 1952; KING 1990, pp. 574-575). ${ }^{4}$ In Thamudic, it is known in al-Theeb and Eskoubi (AL-THeEB 2002, no. 53; AL-THEeb 1999, no. 181; AL-THEeb 2000a, no. 38; EsKouBI 1999, no. 105, 132, 264). We also find it in the Thamudic texts identified by Jaussen and Savignac near Māda'in Șālih (JAUSSEN \& SAVIGNAC 1909, p. 179). Nowadays, it is mostly an element of compound names.

$M h ̣ b b$ : masculine anthroponym recorded in Tabūk's Thamudic inscription (AL-THeEB 1999, no. 181). It is known in Safaitic (Harding 1971, p. 539). A Sabaean inscription also includes this man's name (TAIRAN 1992, p. 92). This name would seemingly correspond to Arabic maḥbūb محبوب, a passive participle from the root $H b b$ "to love."

d'lMzn: set composed of $\underline{d}$, which is the relative "that of, of," followed by ' $l$, which refers back to the ancestor of the clan who, in our case, is Mzn. This clan name is attested in another inscription, discovered in an area very close to the block in question, in wādī Umm Saḥm (FARÈs-

2. This text was published in 1996 (FArĖs-Drappeau 1996, p. 279).

3. See Harding 1971, the index of Jaussen \& Savignac 1909 and 1914.

4. The texts are: Harding \& LitTMAnN 1952, nos. 39, 50, 71, 120, 134, 165, 229, 231, 425, 433.
Drappeau 1996, pp. 281-282). ${ }^{5}$ G. King also confirms it in a Thamudic inscription in the region of Ramm (KING 1990, nos. 405/1 and 406/2, p. 621), so does AL-THEeB once, in the region of Tabūk (AL-THEeB 1999, no. 181, p. 170). This clan name is known as Mznt in Nabataean inscriptions (JAUSSEN \& SAVIGNAC 1909, no. 23, p. 183; Cantineau 1930, no. 113). Māzin مازن is a clan of the al-Ḥārit tribe (a northern tribe) (Ibn Hazm, Gamharat, p. 173) and a clan of Azd (a tribe from the south of the Arabian Peninsula) (Ibn Hazm, Ğamharat, p. 330).

\section{RS3. $l-H b b$}

$H b b$ : masculine anthroponym, very common in Thamudic inscriptions of Hầil (AL-TheEB 1999, no. 67) and of Skāka (AL-TheeB 2002, nos. 3, 11, 22/1, 30, 31, 44, 60). It is also known in Safaitic (WINNETt 1957, p. 153; Littmann 1943, p. 313$)^{6}$ and in Winnett's Thamudic inscription (WinNeTt \& ReED 1970, no. 2). Tairan highlights many other similar confirmations in South Arabian (TAIRAN 1992, p. 95). This name is also known in other Thamudic inscriptions, in the theophoric form $H b b^{\prime} l$ in a Lihyanite inscription (FARĖs-DrAPPEAU 2005, D116) and in a Thamudic text found at wādī Ramm (HARDing \& LitTMANN 1952, no. 451). A feminine form Hbbt is vouched for in a Lihyanite inscription (FARÈSDrappeau 2005, D118). It is known in Phoenician as $H b$ (BENZ 1972, p. 307), in Nabataean as Hbbw (AL-MU'AYQIL \& AL-Theeb 1996, no. 68:2) and in Palmyrenian as $\mathrm{Hbbt}$ (STARK 1971, p. 87). $H b b$ brings to mind a name of an Arabic person حبيب, a very common name. ${ }^{7}$

\section{RS 4. l-Brnt}

This anthroponym is unknown in the available lexicons.

In the inscription of wādī Umm Saḥm, the author evokes the $L t$ deity in favour of turning the supporters of the clan $\underline{d}$ 'l Mzn: l-S'd bn Whb-Lh $\underline{d}$ 'l Mzn w-zkrt Lt kll 'sy'n 'l Mzn "by $S^{c} d$ son $W h b-L h$, of the clan of 'l Mzn. May the $L t$ deity remember all the supporters of the Mzn clan." In 1996, I had proposed to read it so "[...] may the $L t$ deity remember all the members of the Mzn clan", which is wrong. "sy' $n$, which is the plural of $\breve{s}$ ' $t$, designates "supporters" in South Arabian (BEEsTON et al. 1982).

6. Other attestations, in Safaitic, are mentioned by AL-TheEB 1999, p. 73.

7. See Ibn Hazm, Gamharat, index. 
RS 5. $l-M^{c} n b n M^{c} z w-d k r D \check{s} r \check{S} b{ }^{c} n b n{ }^{`} b d-{ }^{`} b d t$

$M^{`} n$ son of $M^{c} z$. Let the God $D \check{s} r$ remember $\check{S} b{ }^{`} n$ son of ' $b d-{ }^{c} b d t$. 'bdt.

It's about an invocation in favour of $\breve{S}^{c} n$ son of ' $b d$ -

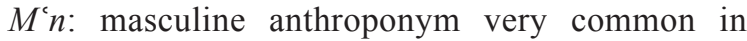
pre-Islamic Arabia. It is confirmed in the Thamudic inscriptions of Ramm (HARDING \& LITTMANN 1952, nos. 80, 300; KING 1990, nos. 78, 351), in the Thamudic inscriptions of al-Jawf (AL-THEEB 2000a, nos. 24, 135, $181,188)$ and in a Thamudic inscription of Jaussen and Savignac (JAUSSEN \& SAVIGNAC 1914, no. 195). It is very common in the Minaean texts of al- 'Ulā as a reigning patronym (JAUSSEN \& SAVIGNAC 1914, nos. 7, 11, 12, 13, 14, 15, 17, 28, 30, 31), known in Safaitic (LitTmann 1943, pp. 1, 23) and Palmyrenean (STARK 1971, no. 96), and in

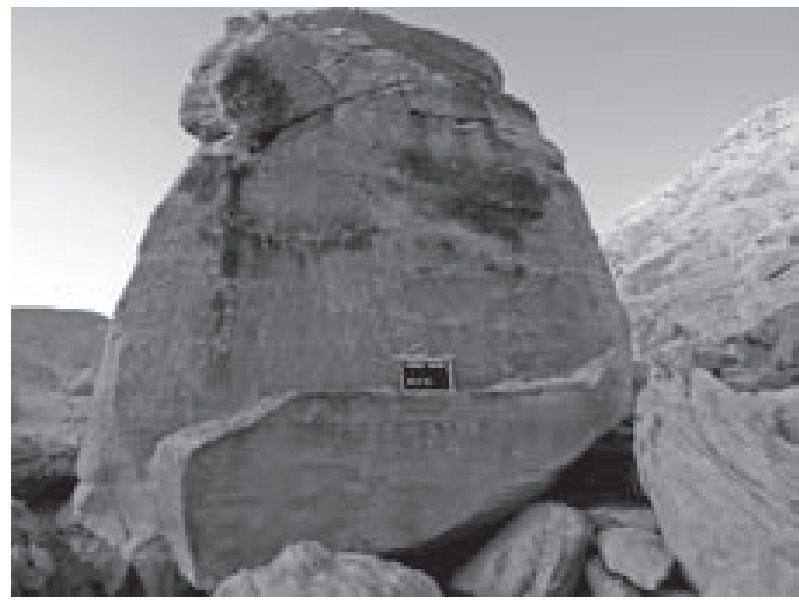

Figure 2 - East view of the block.

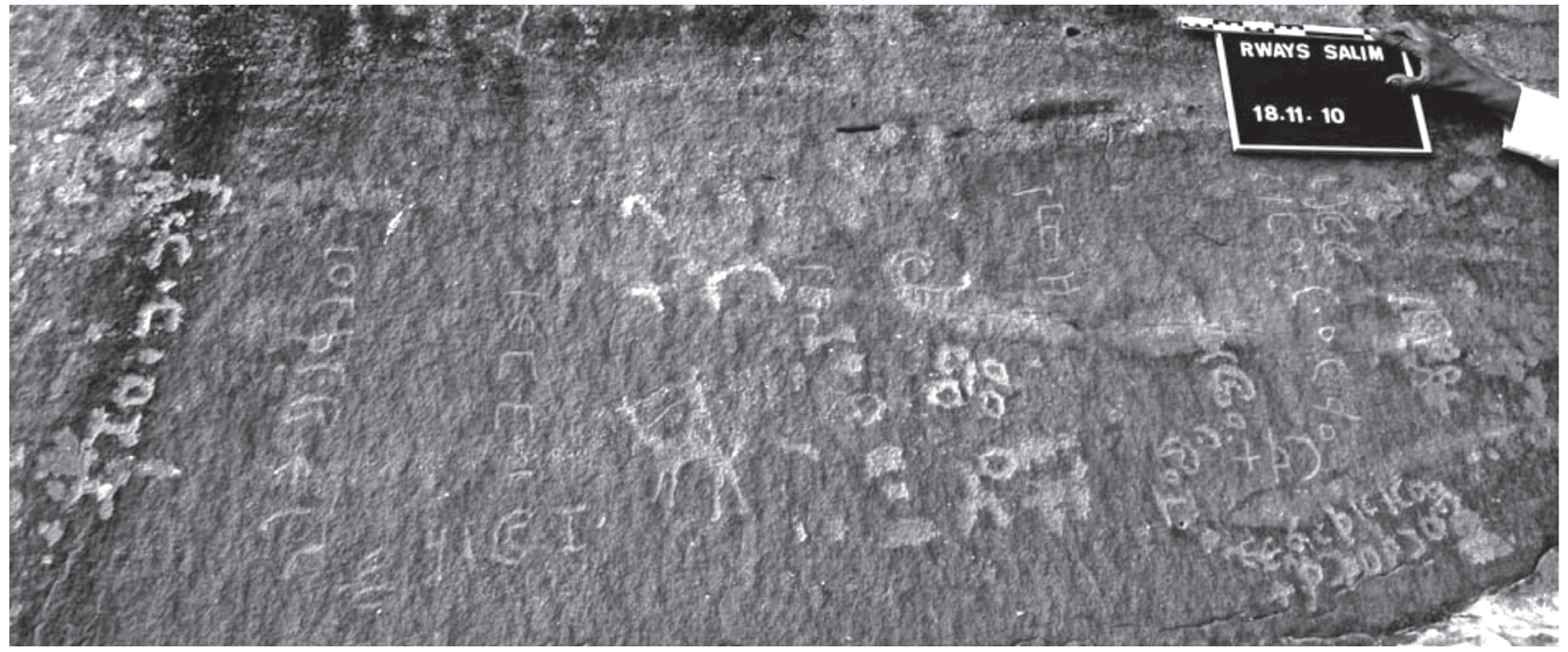

Figure 3 - The upper part.



Figure 4 - Drawings of the upper part (C Jérôme Norris). 
Nabataean it has the form of $M^{\prime} n w$ (CANTINEAU 1930, no. 117). It is name of a person, common in Arabic (Ibn Hazm, Gamharat, index, p. 640).

$M^{\prime} z$ : patronym confirmed in Thamudic (KING 1990, nos. 86, 145, 555; JAUSSEN \& SAVIGNAC 1914, no. 626; HARDING \& LitTMANN 1952, no. 499). It is also known in Arabic (Ibn Ḥazm, Ğamharat, index, p. 640).

$\underline{d} k r$ : verb "to remember," very common in invocations. It appears in Thamudic inscriptions at Ramm (HARDING \& LITTMANN 1952, nos. 45, 58, 156, 170, 481, 489, 506, 520, 521; KING 1990, p. 684). It also appears in Thamudic, in the feminine (AL-THEEB 1999, nos. 174, 181). It is confirmed in Minaean (JAUSSEN \& SAVIGNAC 1914, nos. 330, 369) and in Lihyanite (JAUSSEN \& SAVIGNAC 1914, no. 481).

$D \check{s} r$ : theonym known in Ramm inscriptions (HARDING \& LitTMANN 1952, no. 502; KING 1990, no. 369). It is also known, in the region of Ramm, in the form D $\check{s} r$ (KING 1990, no. 260). It appeared in an inscription within the museum of the University of King Saud's collection (AL-TheEB 2003, no. 56, p. 120). The theophoric tmdšr is known in Nabataean (CANTINEAU 1930, no. 156). It is generally accepted that it is about the Nabataean God $\underline{d}$-Šry (Haussig 1965, pp. 433-435; Healey 2001, pp. 87 101). The Nabataean god $\underline{d}-\check{S} r y$ consists of two elements: the relative $\underline{d}$ and the noun $\breve{S} r y$, which refers back to the mountain range of Šarāt (STARCKY 1956, p. 220-222). This mountain range extends from Ma'ān to Rās anNaqab. One of the peaks is Jabal Hārūn, at the southwest of wādī Mūsa, where the Nabataean capital, Petra, is situated. It should be noted that this mountain range is halted by the depression of an-Naqab, where the sandy region of Hijāz begins. One hundred kilometres separate Rās an-Naqab from wādī Ramm.

The interpretations accepted so far concerning the reading of this theonym proceed by geographical continuity, attributing the same reading to the region of Ramm and its population as to the region of Petra. Today, this extension of meaning to Ramm seems, to us, to have been too hasty. The graffiti around Ramm leads us to propose another reading, which takes Ramm, and no longer Petra, to have been the geographical centre. Assuming, instead, that Ramm is the cultural centre would allow for an analysis of the word as it appears the most often, in other words, in the form of $d-\bar{s} r / \underline{d}-\bar{s} r y$. This would also allow us to consider that the local population had proper beliefs, independently of those of Petra's, and this would be admitting that the population of Ramm had been able to develop its own culture, and create a cult and symbols that corresponded to their local material reality (LEROI-GOURHAN 2001, p. 6).

Only a detour through the facts could guide us along the path of comprehending Ramm's religion. At this point, we can only formulate hypotheses; so difficult it is to understand the religious phenomena, especially in ancient nomadic societies, whose cult objects have disappeared. They were, in fact, perishable elements: sacrificed animals, words, prayers. Only some succinct inscriptions and rock engravings remain, such as those carried by the block we are examining here.

First reflexion: If we assume that $\underline{d} / d$ is a relative ("that of"), the root ŠRY can refer to a quality or to a name as generally is the case. According to al-Mu'jam al-wasit t الثّرى means: "pruritus, itching that resembles scabies; mountain; place abundant with lions; it is said: they are Šarà's lions, in other words, they are



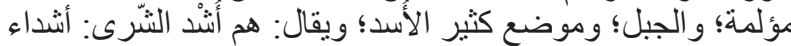
Let us note, by the way, the name Jupiter in Arabic, whose root is $\check{S} r y$. Is $\breve{S} r y$ therefore the equivalent of the Roman God Jupiter or the Greek God Zeus? In any case, we observe that the root of the word, as well as the invocations that are linked to it, evoke strength and fertility.

If we assume, as second reflexion, that the root is $D \check{s} r$, then we could explain the transition of the relative $\underline{d}$ to the radical $d$ through well-known linguistic changes of interdentals in Semitic languages: $\underline{t} / t, \underline{d} / d$ (Moscati et al. 1980, p. 29). If one wants to search for a meaning of this word in Arabic, one quickly finds that the roots DŠR and DŠR are absent from Arabic dictionaries. On the other hand, the root DSR exists in the sense of "to

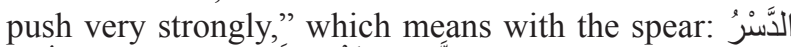

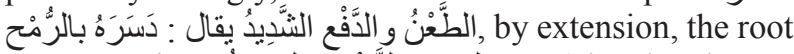

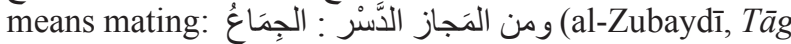
al-' $\operatorname{cor} \bar{u} s$, under the entry DSR). The transition of $\sin$ to šin is a phenomenon also known in Semitic languages (Moscati et al. 1980, pp. 36-37) and is widespread still in our day within different Arabic dialects, such as in the Syrian-Lebanese dialect today, where šajara ("tree") is sajra.

Failing to have a rich corpus containing this theonym, it is currently difficult to know its true written form. However, despite this hindrance, one thing is certain: it seems awkward to us that it refers to the mountain of Sharà, at Petra. Its etymology, suggested above, refers either to a "strong god" or to the god of "fertility." These are the two attributes that a nomadic society needs, in order to face a difficult daily life. ${ }^{8}$

$\breve{S} b^{c} n$ : masculine anthroponym. It is neither authentidated in the Thamudic corpus of al-Theeb neither in those

8. To study the religious phenomena of nomadic societies calls for the same methods and the same prudence as to study prehistoric societies: they left only clues, no monumental remains. The method of comparing religious phenomena of Ramm to those of Petra deprives us of opening towards the discovery of a history specific to this territory in Ramm. See also (Leroi-Gourhan 2001, especially the introduction, pp. 1-9). 
of G. King and neither in those of Jaussen and Savignac. This name corresponds to the Arabic شبعان, which means "replete." It refers to the name of a man known in the Arabic corpus.

' $b d$-' $b d t$ : patronym composed of two: ' $b d$ - "servant of" and ' $b d t$ "submission to God, adoration." It is the name borne in particular by Nabataean King Obodas the first, who ruled between 96 and 87 BC (STARCKY 1966, p. 911). The first element enters into the composition of many theophoric names. ${ }^{9} \quad b d$ corresponds to the Arabic عبد: which equally enters into many theophoric names etc. It is verified in two inscriptions at Ramm as a person's name (KING 1990, KJC 574; HARDING \& LitTMANN 1952, no. 115) and confirmed in al-Jawf's Thamudic inscription (AL-THEeB 2000a, no. 147) and in Safaitic and Nabataean inscriptions (HARDING 1971, index). Additionally, ' $b d$ - ' $b d t$ is the name of a member of the family of a very well-known sculptor at Petra, around the year 40 BC (JAUSSEN \& SAVIGNAC 1909, nos. 3/9, 4/8, $7 / 8$, index p. 492; HeAley 1993, p. 93). ${ }^{10}$ ' $b d$ - $b d t$ is also the name that appears in the cartouche at the entrance of a rock tomb at Petra (Milik \& STARCKY 1975, p. 115).

RS 6. $l-\check{S} b{ }^{c} n b n{ }^{'} b d^{c} b d t$

$l-\check{S}^{\prime} b n$ son of ' $b d^{c} b d t$.

It's about the same person as the preceding text.

RS 7. l-Gmm

Proper name of a man known in Thamudic inscriptions (AL-Theeb 2003, no. 27; Winnett \& ReEd 1973, p. 95; HARDING \& LitTMANN 1952, p. 76) and in Safaitic inscriptions (LitTMANN 1943, p. 39).

RS 8. $l-M^{c}[s] t$

Word unknown in the corpus.

\section{LOWER PART (figures 5 and 6)}

RS 9. l-'s-Lhw- $\underline{d} k r t L t$ ' $h w y k l l-h m$

's-Lh. May $L t$ remember all their brothers.

An invocation formulated by 's- $L h$ in favour of all their brothers.

9. Cf. Harding's index where he references all occurrences (HARDING 1971).

10. This family of masons is also verified in an inscription found by Jobling and Bennet in the region of Ramm (JoBLING \& BENNET 1982, no. 141).
's-Lh: Name of a theophoric person very widespread in Thamudic texts at Ramm (FARÈs-DrapPEAU 1996, p. 276; HARDING \& LiTTMANN 1952, nos. 5, 20, 61, 85, 441, 487, 504; KING 1990, p. 477). 's has the meaning of "to give," and is widespread as a person's name (HARDING 1971, index). ${ }^{11}$ It is also the name of a large Arab tribe at the beginning of Islam الأوس.

$L t$ : feminine divine name "the goddess." She is the goddess at Ramm near Dšr. A temple is dedicated to her in Ramm (FARÈs-Drappeau 1996; Zayadine \& FARÈs-DraPPEAU 1998). There, in Ramm, she appears in numerous texts (HARDING \& LitTMANN 1952, nos. 8, 58, 156, 170, 481, 489, 506, 520, 521; KING 1990, p. 614). ${ }^{12}$

'hw-y: word composed of noun 'h "brother," of $w$ indicating the plural ${ }^{13}$ and $-y$, which, when suffixed to names, designates possession (Moscati et al. 1980, p. 83). ' $h$ is attested in Thamudic in the masculine form (HaRding \& LitTMANn 1952, no. 127; KING 1990, p. 471) and in the feminine 'ht (HaRding \& LitTMANN 1952, no. 522). It is also known as the possessive of the first person singular ' $h-y$ "my brother" (KING 1990, p. 472), of the third person singular ' $h-h$ "his brother" (AL-THEEB 2000a, nos. 24, 54, 57; AL-Theeb 2003, nos. 24, 59; ALTheEB 2002, no. 80), and in the feminine form with the third person of the masculine singular " $h t-h$ "his sister" (AL-THeeb 2000a, no. 138). It is known in Lihyanite in the form of " $h-h$ "his brother," ' $h-h m$ "their brother" and ' $h t-h$ "his sister" (FARÈs-DrappeAu 2005, lexique, p. 249). It enters into the composition of names, such as ' $h$-' $b$ (FARÈs-DraPPEAU 2005, lexique, p. 249; KING 1990, p. 471).

Kll-hm: adverb composed of kll "all" followed by the suffix of the third person plural $-h m .{ }^{14}$ It is quite common in Thamudic inscriptions (FARÈs-DrAPPEAU 1996, p. 282; King 1990, KJ 30, 42, 44, 181, 641; GRAF \& ZwetTler 2004, p. 74).

RS 10. $l-T \ldots$ bn Tm- ${ }^{c} b d t b n \check{S} f r$

$$
T \text {... son of } T m{ }^{`}{ }^{`} b d t \text { son } \check{S} f r \text {. }
$$

11. It is known in Lihyanite as an anthroponym (FARÈs-DrAPPEAU 2005, D7/4, 52/1 and D158/3). In Lihyanite, 's with the article is a name borne uniquely by the king: $h n$ - ' $s$ (FARÈS-DRAPPEAU 2005, D7/4, 12/1, 53/9, 56/6, 58/12, 92/6, 146/9).

12. This deity is known since the $5^{\text {th }}$ century but it is during the Roman period ( $1^{\text {st }} 3^{\text {rd }}$ century AD) that her cult became more widespread among Arab tribes (STARCKY 1981). Nevertheless, $L t$ is one of the three most venerated Arab deities of the preIslamic Arab pantheon, the other two being al-Manāt and al-'Uzzà.

13. On this subject see Lihyanite grammar in FARÈS-DrAPPEAU 2005 , p. 69.

14. See the plural in the Lihyanite texts (FARÈs-DrapPEAU 2005, p. 67). 


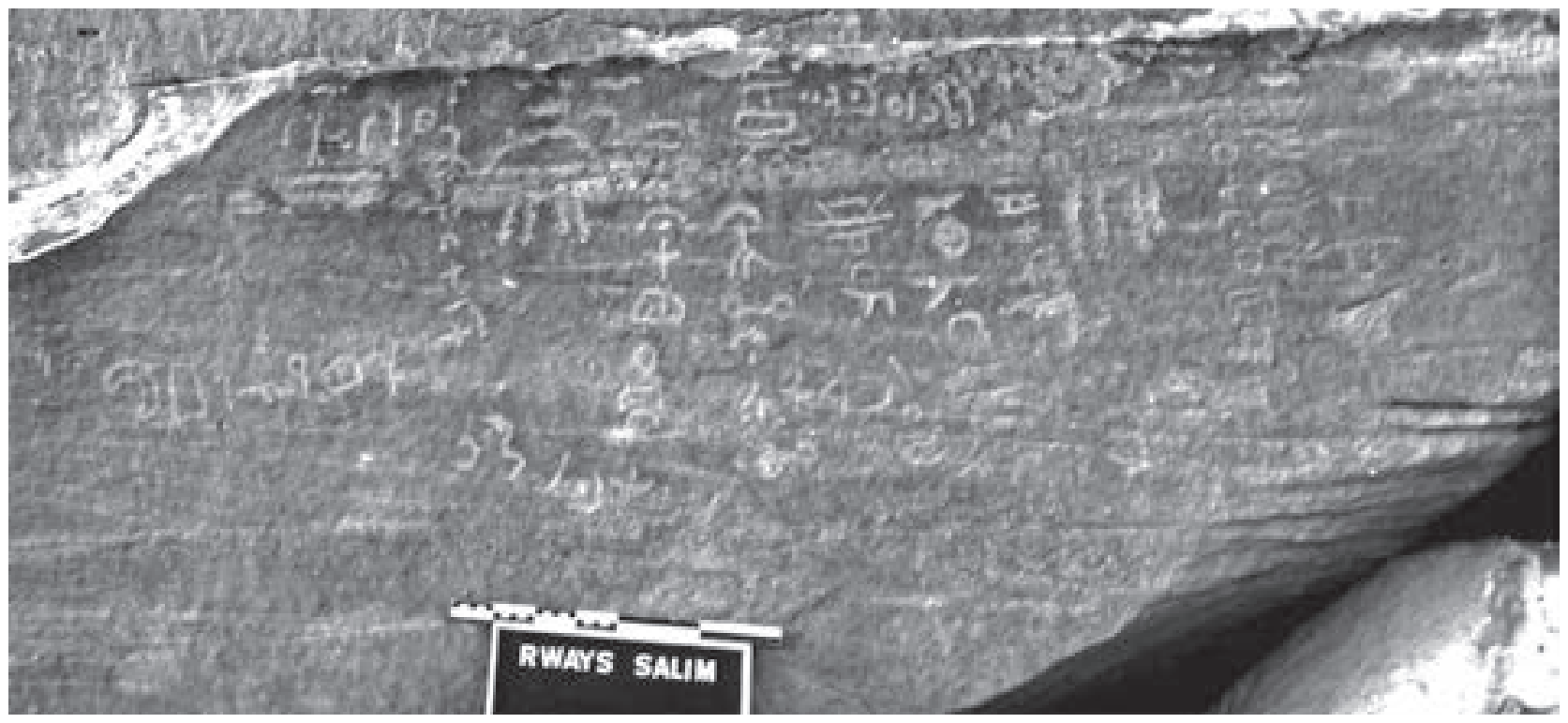

Figure 5 - The lower part.

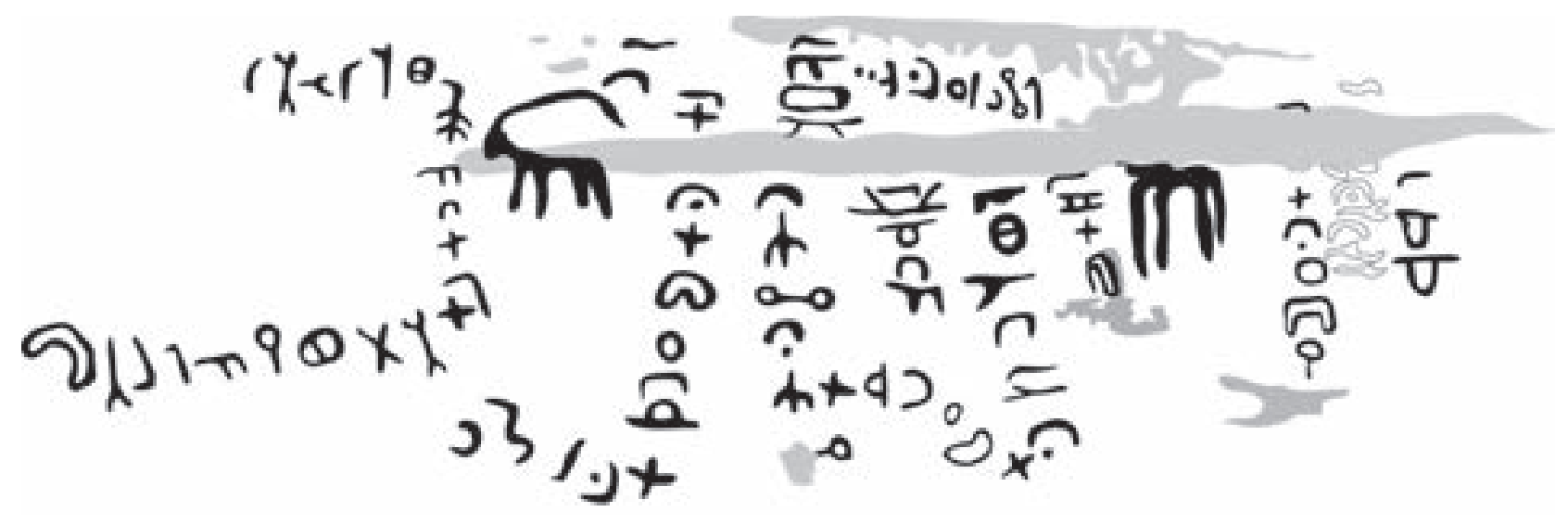

Figure 6 - Drawings of the lower part (C Jérôme Norris).

$T m$ - 'bdt: patronym composed of two elements. $T m$ is a Semitic root meaning "completeness, integrity." 15 This name enters in the composition of theophoric names: $T m-L t, T m-H r$ (HARDING \& LitTMANN 1952, nos. 28, 482, 323). $T m$ - ${ }^{\circ} d t$ is affirmed in Thamudic inscriptions of the region of Ramm (HARDing \& LitTMANN 1952, no. 190 KING 1990, index).

Šr : patronym. This patronym is also known at Ramm (HARDING \& LitTMANN 1952, nos. 171 and 190; KING 1990, p. 562).

15. For various Aramaic and Biblical proofs, cf. BRown et al 1985.

\section{RS 11. $l-K m$,}

$K m^{\prime}$ : proper name of a man, evidenced in the region of Ramm (HARDing \& LiTTMANN 1952, no. 93; KING 1990, p. 611).

RS 12. $l-H g$ bn $H[\ldots]$

$H g$ son of $H[\ldots]$.

$\mathrm{Hg}$ : masculine anthroponym, the patronym has faded away. $\mathrm{Hg}$ is a common name, the Semitic meaning of which is "pilgrim, the celebration linked to pilgrimage." This name is affirmed by Harding in the region of Ramm, but read as $H \underline{t}$ (HARDING \& LitTMANN 1952, nos. 221 and 
426). ${ }^{16}$ It is also known in King's inscriptions, likewise in the region of Ramm (KING 1990, p. 514).

\section{RS 13. $l-G r \check{s} ` b n H n n$}

l-Gršc son of Hnn.

Grš: masculine anthroponym exhibited at Ramm (Harding \& LitTMANN 1952, nos. 13 and 402; King 1990, p. 509), in Thamudic inscriptions of the region of Sakāka (AL-TheEB 2002, nos. 7, 86, 108) and in the region of Jubba, near Hā'il (AL-THEEB 2000b, no. 69). It is also known in Nabataean (CANTINEAU 1930, no. 80) and in Safaitic (HARDING 1971, p. 158).

Hnn: patronym known in Thamudic inscriptions in the region of Ramm (HARDING \& LitTMANN 1952, p. 359; KING 1990, p. 645). It is also found in Safaitic (Dussaud \& MACLER 1901, no. 191a).



'drk: word unknown in the corpus. Does it refer to a masculine anthroponym?

\section{RS 15. $l-W h b-L h b n T m-{ }^{`} b d t$}

\section{l-Whb Lh son of Tm- ' $b d t$.}

Whb-Lh: very common theophoric masculine anthroponym, "gift of $L h$." It is affirmed in the Thamudic inscriptions of Ramm (HARDing \& LitTMANN 1952, nos. $37,70,78,85,87,145,157,190,217,230,309,368$, $460,484,487$; KING 1990, p. 653-654). It is also known in the Thamudic inscriptions in north and northeast Arabia (AL-Theeb 1999, no. 181; AL-Theeb 2000a, nos. 29, 54). It appears in the Lihyanite inscriptions of al- 'Ulā (FARĖSDRAPPEAU 2005, D13/1, 15/1, 21/1, 58/1). The element Whb is confirmed as a proper name of a man "gift" or as an element of theophoric names. In this way it is known in composition with $L t$ in the Thamudic inscriptions of alTheeb (AL-Theeb 2000a, no. 27; AL-TheeB 1999, no. 67; AL-TheeB 2003, no. 7). In Nabataean it has the form of Whb-lhy, Whb-'lh, Whb-'Ih (CANTINEAU 1930, p. 89). ${ }^{17}$

RS 16. $l-\underline{-} t[\ldots]$

The text is eroded; only three letters are still readable.

16. The letter $\xi$ is a gim in the inscriptions of the region of Ramm and a $\underline{t} a^{\prime}$ in the region of al- 'Ulā.

17. The number of theophoric names in the composition, of which the name $W h b$ is one, is too large. I refer to Harding's index (HARDING 1971), even if hundreds of texts have since been published in which this name has appeared.
RS 17. $l-[\ldots]$ t bn ' $m y[\ldots]$

$$
l-[\ldots] t \text { son of ' } m y[\ldots] \text {. }
$$

'my: text also eroded.

To sum, these texts, despite their brevity, give an insight into Thamudic lexicon and syntactical construction. It is a question about a structure specific to Arab graffiti. These texts are the expression and language of a people who have their own representation of the world that translates their own system of thought. The word order, so regular, leads us to question the representation that these people had of the world, and consequently, of the religious facts/events that the texts convey. Durkheim's reflexions on the "The leading conceptions of the elementary religion" (DURKHEIM 1915, pp. 68-83) provide us ideas concerning language; by ordering and classifying words in a style unique to each society, it expresses a system of representation of the world of these people. ${ }^{18}$

1/ Filiation: Reference to ancestry (nasab, which is the link of horizontal kinship) is introduced by $b n$ "son of" (or bnt "daughter of," but this is rare). Reference to the eponymous ancestor, hasab, is introduced by $\underline{d}$ 'l "those of the community of, of the group of" (RS 2). The etymology of the Arabic word means: "origin, first, return to," it is derived from the word 'awwal

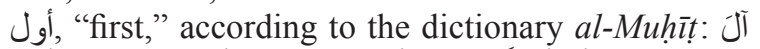

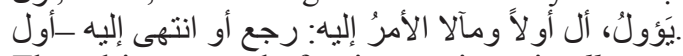

2/ The ultimate verb for invocations is $\underline{d} k r$, even if other verbs are demonstrated (HARDING \& LitTMANN 1952, index; KING 1990, index). Dkr is a Semitic root meaning "remember of, pay attention to." In our text (RS 5), the subject of the verb is the theonym $D \check{s} r$, while in (RS 9) the subject is $L t$. This verb is most often used in North Arabian texts: (KING 1990; FARÈsDrappeau \& ZaYADINE 2005; FuJII \& TOKUNAGA 2007; ZAYADINE \& FARÈs-DraPPEAU 1998). ${ }^{19}$ It is known only in the third person singular, masculine or feminine, depending on whether the subject is a god or goddess. $D k r$ especially appears in a religious sense, of which the theonyms are the subject. This verb is known in the Nabataean inscriptions of 'Ayn ash-Shallālah at

18. "Thinking consists in arranging our ideas, and consequently in classifying them. [...] But classifying is also naming $[\ldots]$. Thus the language of a people always has an influence upon the manner in which new things, recently learned, are classified in the mind and are subsequently thought of; these new things are thus forced to adapt themselves to pre-existing forms. For this reason, the language which men spoke when they undertook to construct an elaborated representation of the universe marked the system of ideas which was then born with an indelibly trace" (DuRKHEIM 1915, p. 75).

19. The bibliography is very long, thanks to intense epigraphic exploration in Saudi Arabia. 
wādī Ramm, where we have the same formula as in our texts (SAVIGNAC 1933) ${ }^{20}$. In the region of Tabūk (Saudi Arabia), this verb is known in the feminine (the subject is the deity $L t$ ): nos. 174 and 181 (AL-THEeB 1999, pp. 165-170). In Harding-Littmann's Thamudic inscriptions, it is likewise known in the feminine form in the inscriptions nos. 45, 58, 156, 170, 481, 489, 506, 520 and 521 (Harding \& LitTMANN 1952). It is known in King's inscriptions (KING 1990, index) and affirmed in Safaitic inscriptions, in north Jordan and south Syria (LitTMANN 1943, no. 85).

$3 / w$-, which precedes the verb, is generally translated as "and," 21 or can have more complex uses than simple coordination. Arab grammarians have listed several uses including that of invocation الاستغانة, which is the meaning we will retain in our translation.

Finally, a word on onomastics. Anthroponyms are widely spread in the Arabic realm, some of which are still used today. On the other hand, the name of the lineage $M z n$ seems to be limited to the region of Ramm and spreads itself to the region of Tabük in the south. The period to which these texts date is difficult to know. If some see an indication of the Nabataean epoch in the anthroponym ' $b d$ - $b d t$ or the rapprochement $M z n / M z n t$, for my part, these indications no more reveal the Nabataean epoch than later epochs. Only datable remains, as archaeological type, would bring confirmation.

In sum, what does this block with inscriptions tell us? Does the block itself, its location and invocation associated to a clan name, indicate a delimitation of territory? Only exhaustive work of the entire body of Thamudic study could give us a response. In any case, these texts provide us with the additional pieces of information to study the linguistic and social facts of a nomadic, pre-Islamic society, whose culture left many traces in Islamic religions.

saba.fares@univ-tlse2.fr Université Toulouse - Jean Jaurès, Patrimoine, Littérature, Histoire (EA 4610)

20. Thirty texts are invocations to $L t$. The verb employed is always $\underline{d} k r$. For further example, cf. no. 3 : $d k r{ }^{\prime} l t w$

Hlypw w-Mqm'l

w-Nhșț $w$-h̆qly

$b-t+b$
May God remember Hlypw, Mqm'l, Nhștb and Hqly in good.
21. Sometimes in front of an inscription, in this case, it is considered as an introduction: Cf. by way of example the text no. 129 published by L. Harding: $w$ 's $d b n s^{\prime} d t$ "and Assad son of Sa 'dat" (Harding \& LitTMAnn 1952).

\section{BIBLIOGRAPHY}

Beeston A. F., Ghul M. A., Müller W. W., Ryckmans J.

1982 Dictionnaire sabéen, Louvain-la-Neuve - Beyrouth, Peeters - Librairie du Liban.

BENZ F. L.

1972 Personal names in the Phoenician and Punic inscriptions: a catalog, grammatical study and glossary of elements, Rome, Biblical Institute press.

Brown F., Driver S. R., Briggs C. A., Gesenius W.

1985 A Hebrew and English lexicon of the Old Testament with an appendix containing the biblical Aramaic based on the lexicon of William Gesenius as transl. by Edward Robinson, Oxford, Clarendon press.

CANTINEAU J.

1930 Le nabatéen, Paris, E. Leroux.

DURKHEIM É.

1915 The elementary forms of religious life, transl. by J. Ward Swain, London.

Dussaud R., MAcLER F.

1901 Voyage archéologique au Safâ et dans le Djebel edDrûz, Paris, E. Leroux.

EsKoubi K.

1999 An analytical and comparative study of inscriptions from "Rum" region, southwest of Tayma, al-Riyad, Deputy Ministry for Antiquities and Museums [in Arabic].

FARÈS S.

2013 "Résultats préliminaires des prospections et des fouilles", in Des déserts et des hommes: le wadi Ramm (Jordanie), sous la dir. de S. FARès, Nancy, ADRA, pp. 11-78.

FARÈs-DRAPPEAU S.

1996 "Wady Iram : un lieu du culte et de rassemblement des tribus arabes dans l'Antiquité : les premiers résultats de la mission épigraphique", ARAM 8 (2), pp. 269-283.

2005 Dédan et Lihyān : histoire des Arabes aux confins des pouvoirs perse et hellénistique (Travaux de la Maison de l'Orient et de la Méditerranée 42), Lyon.

Farès-Drappeau S., Zayadine F.

2005 "A preliminary report on the sixth season of the Wâdi Iram epigraphical, geographical and archaeological survey", Annual of the Department of Antiquities of Jordan 45, pp. 350-375.

II S., ToKunaga R.

2007 "A brief report on Hismaic inscriptions from Ras Abū Tulayha in the Jafr Basin, southern Jordan”, Annual of the Department on Antiquities of Jordan 51, pp. 361-372.

Graf D. F., ZwettLer M. J.

2004 "The North Arabian 'Thamudic E' inscription from Uraynibah West", Bulletin of the American Schools of Oriental research 335, pp. 53-89. 
HARDING G. L.

1971 An index and concordance of pre-Islamic Arabian names and inscriptions (Near and Middle East series 8), Toronto.

Harding G. L., LitTMann E.

1952 Some Thamudic inscriptions from the Hashimite Kingdom for the Jordan, Leiden, Brill.

Haussig H. W.

1965 Götter und Mythen im Vorderen Orient, Stuttgart, E. Klett.

Healey J.

1993 The Nabataean tombs inscriptions from Mada'in Salih, Oxford, Oxford University press.

2001 The religion of the Nabataeans (Religions in the Graeco-Roman world 136), Leiden, Brill.

Ibn Hazm, Ğamharat: 'Ali ibn Aḥmad Ibn Hazm, Ğamharat ansāb al-'arab, Bairūt, Dār al-kutub al-'ilmiyya, 1983.

JAUSSEN A., SAVignac R.

1909 Mission archéologique en Arabie. 1, Mars-mai 1907 : de Jérusalem au Hedjaz-Médaine-Saleh, Paris, Geuthner.

1914 Mission archéologique en Arabie. 2, El-'Ela, d'Hégra à Teima, Harrah de Tebouk, Paris, Geuthner.

Jobling W., Bennet C.

1982 "The Aqaba-Ma'an archaeological and epigraphical survey", Annual of the Department of Antiquities of Jordan 26, pp. 199-209.

KING G.

1990 Early North Arabian Thamudic E : a preliminary description based on a new corpus of inscriptions from Hismâ Desert of Southern Jordan and published material, unpublished $\mathrm{PhD}$ thesis, School of Oriental and African Studies, University of London.

LeRoI-Gourhan A.

2001 Les religions de la préhistoire, Paris, PUF.

LiTTMANN E.

1943 Syria: publications of the Princeton University archaeological expeditions to Syria in 1904-5 and 1909. 4, Semitic inscriptions. C, Safaitic inscriptions, Leiden, Brill.

Milik J. T., Starcky J.

1975 "Inscriptions récemment découvertes à Pétra", Annual of the Department of Antiquities of Jordan 20, pp. 116-119.

Moscati S., Spitaler A., Ullendorff E., Soden W. von

1980 An introduction to the comparative grammar of the Semitic languages, Wiesbaden, Harrassowitz.

Mu'AYQIL K. AL-, Al-TheEB S.

1996 Al-'ātār wa al-kitābāt al-nabatiyya fì al-Jawf, alRiyad, Maṭa`at Khalid.
SAVIGNAC R.

1933 "Le temple d'Allat à Iram", Revue biblique 42, pp. 413-415.

STARCKY J.

1956 "Palmyréniens, Nabatéens et Arabes du Nord avant 1'Islam", in Histoire des religions. 4, publ. sous la dir. de M. Brillant et R. Aigrin, Paris, Bloud \& Gay, pp. 201-237.

1966 "Pétra et la Nabatène", Supplément au dictionnaire de la Bible. 7, Paris, pp. 886-1017.

1981 "Allath", Lexicon iconographicum mythologiae classicae (LIMC). 1, Aara - aphlad, Zürich, pp. 564-570.

STARK J. K.

1971 Personal names in Palmyrene inscriptions, Oxford, Claredon.

TAIRAN S.

1992 Die Personennamen in den altsabäischen Inschriften, Hildesheim, Georg Olms.

AL-Theeb S.

1999 Nuqūš Tamūdiyya min al-Mamlaka al-'Arabiyya as-Sa'ūdiyy, al-Riyaḍ, Maktabat al-Malik Fahd alwațaniyya.

2000a Dirāsa li-nuqūš tamūdiyya min Gubba bi-Hā̉il, alRiyad, Maktabat al-Malik Fahd al-wațaniyya.

2000b Nuqūš Qārā al-țamūdiyya bi manțqat al-Jawf, alRiyaḍ, Mu'assasat 'Abd al-Raḥmān al-Sudayri alKhayriyya.

2002 Nuqūš Tamūdiyya min Skāka, al-Riyaḍ, Maktabat alMalik Fahd.

2003 Nuqūš șafawiyya min šamālī al-Mamlaka al'arabiyya as-Sa'udiyya, al-Riyad,, Mu'assasat 'Abd al-Raḥmān al-Sudayri al-Khayriyya.

WINNETT F. V.

1957 Safaitic inscriptions from Jordan, Toronto - Oxford, Toronto University press - Oxford University press.

Winnett F. V., REED W.

1970 Ancient records from North Arabia, Toronto, Toronto University press.

1973 "An archaeological-epigraphical survey of the Ha'il area of Northern Sa'udi Arabia”, Berytus 22, pp. 53-113.

ZAYADINE F., FARÈs-DrapPEAU S.

1998 "Two North-Arabian inscriptions from the temple of Lât at Wady Iram", Annual of the Department of Antiquities of Jordan 42, pp. 255-258.

al-Zubaydī, Tāg al-'arūs : M. M. al-Husaynī al-Zubaydī, Tāg al-`arūs, vol. 16, Kuwait, 1973. 


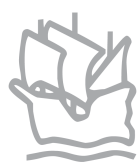

(C) BREPOLS PUBLISHERS

THIS DOCUMENT MAY BE PRINTED FOR PRIVATE USE ONLY

IT MAY NOT BE DISTRIBUTED WITHOUT PERMISSION OF THE PUBLISHER 